\title{
CONTRIBUTION OF API-NAMPA CONSERVATION AREA ON THE LIVELIHOOD OF POOR AND DISADVANTAGED PEOPLE OF DARCHULA DISTRICT, NEPAL
}

\author{
B. Shakya ${ }^{1 *}$ and R. R. Pant ${ }^{2}$ \\ ${ }^{1}$ Department of Botany, S.S. Campus, Tribhuvan University, Mahendranagar, Nepal \\ ${ }^{2}$ Central Department of Environment, Tribhuvan University, Kirtipur, Nepal. \\ *bimalshakya2012@gmail.com
}

\begin{abstract}
The study was carried out in the community forests of Latinath and Khandeswori Village Development Committees (VDCs) of Api-Nampa Conservation Area, Nepal. The life style in the area is very primitive and close to nature and the area has diverse forest and ecosystem that provide diverse habitat for wildlife. The study demonstrates that, among the five capitals assessed, the condition of financial capital is the worst where as that of physical capital is the best. The condition of other three capitals (Human, Social and Natural) is satisfactory. The findings of this research conclude that the conservation area has played a significant role in livelihood upliftment of the people in the study area. It may have been too early to draw this conclusion as the conservation area was established only in 2010, however, the studied community forests have been used since last fifteen years. Fuel wood is an exclusive source of cooking fuel in both the VDCs. Demand and supply gap of fuelwood in Khandeswori VDC is comparatively higher because the huge amount of fuelwood is used for heating purpose in the winter. The insufficient supply from the community forest compels the locals to use the nearby conservation area forest to meet up with the need.
\end{abstract}

Key words: Api-Nampa, community forest, conservation, disadvantaged people, livelihood.

\section{INTRODUCTION}

Nepal is linked with six phyto-geographical provinces and over 47 types of vegetation represented in the protected areas (PAs) of Nepal. Mountain protected areas of Nepal Himalaya represents the highest terrestrial ecosystem of the earth. Indigenous knowledge provides invaluable knowledge and aid in making the best out of natural resources. Nepal, with very high cultural diversity and with varied climatic conditions, is provided with highly diverse ecosystems, which means there is a large number of plant species to be used for various purposes.

\section{PROTECTED AREA AND LIVELIHOOD}

The number of protected areas has grown exponentially over the past two-three decades, particularly in developing countries like Nepal. This mission of protected areas has expanded from biodiversity conservation to improving human welfare. Conserving biodiversity beyond Protected Areas (PAs) seeks to address root causes of biodiversity loss and promote biodiversity at a landscape scale. The record also recognizes the sovereignty of local people over forest areas and their potential role in determining management regimes (Buck et al., 2007; Cincotta and Engelman, 2000). Protected 
areas are expected to directly contribute to national development and poverty reduction (Naughton-Treves et al., 2005; Redford and Fearn, 2007).

In a country like Nepal, where over $95 \%$ of the population directly depends on the forests for their need of timber and non-timber forest products (Gautam, 2006), conservation objectives must be linked with the sustainable livelihood of local people. Poor houses have high opportunities cost of participations as the time spent on participation could be used as labor for cash income. In comparison to higher and lower classes, medium class household benefit the most (Pokharel and Nurse, 2004). The conservation goals cannot be achieved without the appreciation of impacts of protected areas on local people or consideration of alternatives. PAs must provide livelihood opportunities for the people living in and around them. In Nepal, community based conservation program was first applied in the Annapurna Conservation area in 1986. With the notable success of conservation program and improvement in the livelihood of the people at the local in the Annapurna Conservation area, Nepal Government has declared other conservation areas and buffer zones in other parts of the country too. In 2010, Nepal Government has established ApiNampa Conservation Area (ANCA) as one of the examples of successful learning from Annapurna Conservation Area. Api-Nampa Conservation Area (ANCA) was established to conserve the biodiversity, ensure sustainable use of the natural resources and at the same time improving the livelihood of marginalized people by promoting tourism and ecotourism. ANCA is the youngest conservation area of Nepal in Far-Western part of Nepal. It provides a very diverse range of habitats hence it has very high potential for conservation of very fragile
Himalayan floral, faunal and cultural diversity. Being a newly established area, a detail study and research have not been conducted in ANCA.

\section{FARMING AND LIVELIHOOD}

Agriculture has been historically viewed by the conservationists as the main threat to biodiversity. Animosity between conservation and agriculture has led to academic and institutional cultures of compartmentalization, distrust, and closed-mindedness to the potential for the co-existence, and indeed mutual benefit, between agriculture and biodiversity (Buck et al., 2007). The Millennium Assessment calculated that more than $45 \%$ of the world's 100,000 protected areas had more than $30 \%$ of their land area under crops. Eco-agriculture is a landscape planning approach which aims to achieve agricultural production and sustain rural livelihoods in ways that also protect wild plant and animal species and the natural ecosystem services upon which both humans and wildlife depend (Buck et al., 2007; Scherr and McNeely, 2008).

\section{MATERIALS AND METHODS}

\section{Study Area}

Present study is focused in two Local Communities of Latinath and Khandeswori Village Development Committees of Darchula district, Far-Western Himalaya region of Nepal (fig.1), that lie within Api Nampa Conservation Area (ANCA). The total area of the ANCA is $1903 \mathrm{~km}^{2}$, in between $29^{0} 15^{\prime}$ north latitudes and $80^{\circ} 09^{\prime}$ east longitudes and 21 Village Development Committees (VDCs) lie within the conservation area within the elevation range of $518 \mathrm{~m}$ to $7132 \mathrm{~m}$. Because of the extreme variation in altitude and the consequent variation in climate, this region is endowed with excellent habitats for diverse flora and fauna including socioeconomic and cultural diversity. There 
are 8,966 households in the region with the population of 54,358. The major ethnic groups are Brahmin, Chhetri, Bhote, Kami, Damai and Sarki (DNPWC, 2013)

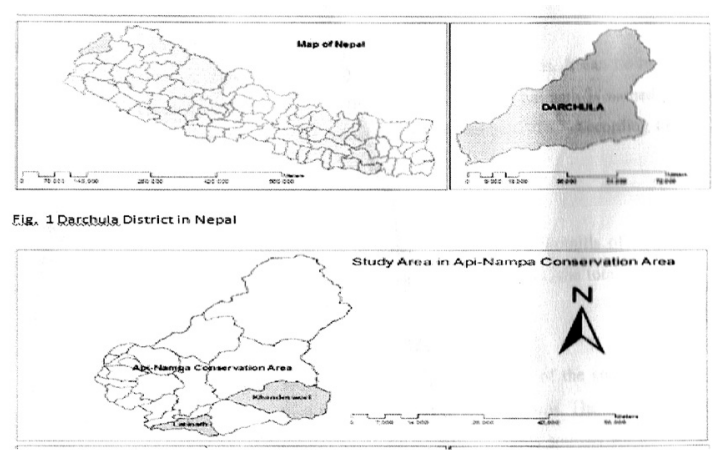

Fig. 1 Darchula, District in Nepal

Fig. 2 Study Area in Api-Nampa Conservation Area

Two VDCs Latinath and Khandeswori of Darchula district, that are located in the ApiNampa Conservation Area, are selected for the present research. VDC Latinath was considered as site A and VDC Khandewori was considered as site B. The two VDCs are very diverse in terms of economic status of the people, biotic components and in terms of bio-physical and socioeconomic environment. The dependency of the people on conversation area is high i.e. the area represents the social, cultural and economic diversity where people mainly depend on resources of conservation area for their livelihood.

\section{Latinath Village Development Committee}

Latinath is very inaccessible region with entirely no connection with roads. It can be reached by 6-8 hours of walk from Gaanna (last point where you can find vehicles). Latinath is named after a saint called Latinath who used to rest at the place called Marma of Latinath VDC. According to the census 2011, the total population of this VDC is 4675 (Fig. 2).

\section{Khandeswori Village Development} Committee

Khandeswori is remote VDC of Darchula district. It is located in the foothills of Api, Nampa and Kayiyo Kor Himals in the Northern region. According to the census 2011, the total population of this VDC is 3151 (Fig. 2).

\section{Data collection}

The intensive field survey was conducted to triangulate the information gathered from the various sources such as consultation meeting, focus group discussion, interview and questionnaire survey etc. For this purpose, both primary and secondary data were collected. The field visit was conducted on 2012-2013 (Fig. 1). During field observation, the research work was focused on the survey of the status and potential of resources and their contribution in the livelihood upliftment of targeted groups.

\section{Primary Data:}

In order to collect the most reliable and useful information regarding the study, primary data were collected by using reconnaissance survey, house hold survey and key information interview.

\section{Secondary Data Collection:}

Various publication including project reports, dissertation reports, books, journals, government policies and plans and electronics materials were collected and studied to gather additional information supporting primary data.

\section{RESULTS}

\section{Community Forestry and Livelihood Capitals}

Fifteen different indicators were used to assess the condition of five capitals: human capital, social capital, natural capital, physical and financial capital and the total score for each of the indicators was calculated followed by an average for each of the capitals. The indicators used for 
physical capital were development in physical infrastructure, effectiveness of construction of such infrastructure and knowledge about running community development activities and were scored as $0.23,0.23$, and 0.30 respectively with total average of 0.76 for Khandeswori VDC and $0.63,0.58$, and 0.48 respectively with total average of 1.69 for Latinath VDC. Similarly, organizing skill development activities, participation on such program and development in leadership capacity which were used as indicators for human capital obtained the scores as $0.15,0.12$, and 0.32 respectively with an average of 0.35 for Khandeswori VDC and $0.22,0.25$, and 0.48 respectively with an average of 0.95 for Latinath VDC. In the similar way, decision making capacity about resource use and management, elation among UG members after handover of forest and individual playing major role in decision making were three indicators for social capital which got the scores of $0.4,0.35$, and 0.10 respectively with an average of 0.85 for Khandesori VDC and $0.60,0.38$, and 0.00 respectively with an average of 0.98 for Latinath VDC. Likewise, drying up of water bodies, improvement in greenery and availability of forest products; the three indicators of natural capital were scored as $-0.10,0.02$, and 0.15 respectively with an average of 0.07 for Khandeswori VDC and $0.23,0.20$, and 0.35 respectively with an average of 0.78 for Latinath VDC. Finally, the three indicators of financial capitals; time and cost of forest products collection, increase in employment opportunity and availability of loan income generating activities obtained a total score of $0.15,0.27$, and 0.00 respectively with an average of 0.42 for Khandewori VDC and $-0.05,0.45$, and 0.30 respectively with an average of 0.70 for Latinath VDC (Fig. 3).

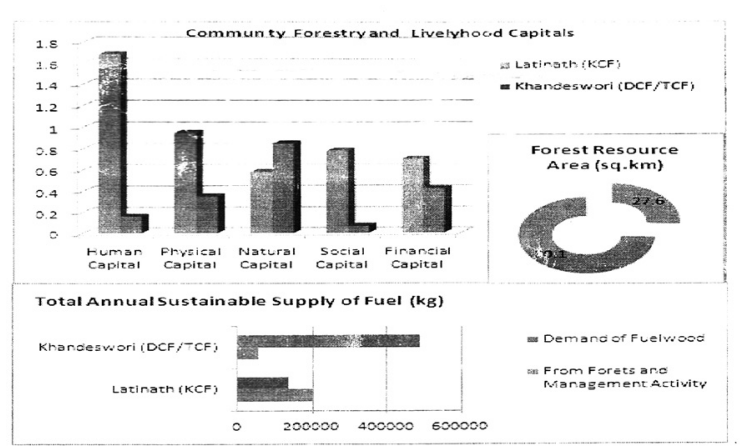

Fig. 3: Community forestry and livelihood capitals

Fig. 4: Forest resource coverage area

Fig. 5: Total annual sustainable supply of fuel

\section{Forest Resource in the Study Area}

According to the data, total area covered by the forest in Latinath VDC is $27.60 \mathrm{~km}^{2}$, although most of the area is still covered by forest but the quality of the forest is very poor with very few large trees. And most of the forest area is inaccessible to the people, hence there is an extra pressure on the accessible forest resources. Total forest area in the Khandeswori VDC is $80.13 \mathrm{~km}^{2}$, the forest in this region is also very dispersed and in degraded state whereas inaccessible forest is still very pristine (Fig. 4).

\section{Demand of the fuelwood}

Fuel wood is used for different purposes like cooking food, preparation of animal feed, heating etc. The amount of fuel wood consumed for each activity in both the CFUG is calculated. The total annual demand of fuel wood in KCFUG is $134890 \mathrm{~kg}$ and the demand for DCFUG and TCFUG is $233673 \mathrm{~kg}$ and $257544 \mathrm{~kg}$ respectively. The demand for the fuelwood is very high in DCFUG and TCFUG because huge amount of fuelwood is used for space heating during cold winters (Fig. 5). 


\section{Energy Use in the Study Area}

Fuelwood is an exclusive source of energy for cooking in both of the VDCs. The major reason behind this is that there is no electricity in Latinath VDC whereas there is electricity in Khandeswori VDC from the small micro hydro project. There is no biogas or ICS in Latinath VDC whereas there is ICS in almost all of the households in Khandeswori VDC which shows a better living practice in Khandeswori VDC. The demand and supply of the study area were assessed for fuelwood. There was no financial use of fuelwood in the study area since most of the people collect the fuelwood by themselves.

5. Contribution of Conservation Area on the Livelihood of Poor and Disadvantaged People

\subsection{Biogas Potential in the Study Area}

Biogas potential depends on the number of cattle in the region. Information on the number of cattle from the study area was collected by questionnaire through household survey. According to survey, the total gas production per day of CFUG in KCF is $64.45 \mathrm{~m}^{3}$. And the total gas production of CFUGs of DCF and TCF are 14.55 and $19.09 \mathrm{~m}^{3}$ respectively.

\subsection{Animal Husbandry as the Means of Livelihood in the Study Area}

The life style in the region is still very primitive and people are heavily reliant on the animals for food (in the form of milk, meat), fiber and as a means of transportation. The data suggests that people of Latinath VDC are more reliant on the cows and buffalos for milk products whereas the people of Khandeswori VDC are more reliant on Mules for the supply of food and other materials. Mules are the lifeline of the both VDCs, there is no road access to the region, and hence all the basic life support materials are brought by mules. According to this survey, there are 341 adult cattle in KCFUG whereas there are 77 and 101 adult cattle in DCFUG and TCFUG.

\subsection{FARMING PRACTICES}

The agriculture production in the Latinath VDC is quite good depending upon the area of field and irrigation facility. There is good irrigation facility in Latinath VDC hence production is quite good and according to the local people, paddy production is often equivalent to the land in Tarai. Farming is one of the major sources of income of the people in Latinath VDC. The climate is very favorable for farming practice and animal husbandry. Due to cold climate, farming practice is not very suitable for Khandeswori VDC and the people in the region are gradually leaving the practice of agriculture due to enough earning from Yarshagumba collection. And also due to cold weather, it takes fairly longer time than usual to harvest the crops.

\section{DISCUSSION}

\section{Livelihood}

Community forestry is proven to improve and diversify the local livelihood by using locally owned natural capitals and the local human capital (Ojha et al., 2009). The result shows that with the handover of the forest to the community within the conservation area, the condition of physical and social capitals have been enhanced a lot, enhancement in human and financial capitals have not been contributed much whereas the natural capital is among the worst in Khandewori VDC. Thus, it can be stated that the overall contribution of community forestry in livelihood contribution is not quite satisfactory in Khandeswori VDC.

The livelihood of this region is largely dependent on the Yarsagumba (Cordyceps sinensis) collection from the Himalayas from the month of March through the start of monsoon usually till May. People are starting to abandon the 
traditional practice of rearing sheep, Himalayan goat, cow and other animals because during Yarsha collection, all the members of the family go to the Himalaya and there is no one to look after the animals. This high level dependence on Yarshagumba makes livelihood of the people more vulnerable. Hence, diversification of livelihood option is highly recommended for the region.

In contrast to this VDC, the condition of all five livelihood assets/capitals have been enhanced a lot in Latinath VDC after the handover of the community forest to the locals. The reason behind this is the lack of accessibility to resources and vulnerability of the people living in the Khandeswori VDC in comparison to Latinath. Overall condition of the five livelihood assets was also assessed taking the average for two VDCs and the result demonstrates that the condition of financial capital was among the worst. This might have been because the handover of the forest to the community had no significant contribution in the employment generation opportunity of the people and equally no any provisions for loan to promote IGAs; the two indicators used to assess this capital. Hence, income generation and capacity building program should be effectively run at local level to address this asset of livelihood assessment. Likewise, the condition of physical capital was among the best as the handover of the forests to the community had helped in the development of physical capitals, improved the effectiveness of construction of physical capitals and enhanced the knowledge about running community development activities.

\section{Fuel wood demand and supply}

Participation of community people in the forest conservation in Nepal is in progress and effective in improving the forest condition. But, still demand and supply of the forest products in the CFUG depicts the shortage of the forest products, mainly the fuel wood. The demand of the fuelwood is increasing with the increasing population and livestock. Shortage of fuel wood is increasing pressure in community and government managed forest. High demand of fuelwood by the locals may be unsustainable which can result in the over harvest from the nearby forest of the conservation area which in turn may result in the loss of biodiversity and subsequent degradation of the forest quality.

The total annual demand of fuelwood in KCFUG is $134890 \mathrm{~kg}$ and the demand of DCFUG and TCFUG is $233673 \mathrm{~kg}$ and 257544 $\mathrm{kg}$ respectively. The demand for the fuelwood is very high in DCFUG and TCFUG because huge amount of fuelwood is used for space heating during cold winters. This high demand for fuelwood indicates the greater chances of forest degradation which may lead to unsustainable forest management and indirectly impacts on the status of floral and faunal biodiversity in the area. This huge gap can be reduced by incorporating some alternative sources of fuelwood like biogas, the potential of which is higher in the study area as illustrated above. Similarly, ICSs can also serve as a better option to fuelwood which, on one hand, reduces the pressure on forest resources and on the other helps to preserve the ecologically important and biologically diverse ecosystems in the study area.

\section{CONCLUSIONS AND RECOMMENDATIONS}

Protected areas can play significant role in the development of the conservation of the forest resources. Still, in country like Nepal, most of the rural people are heavily reliant on the natural resources. This dependence can work both as an opportunity to allow local people to contribute to the conservation and also as a challenge to 
conservation activities. The status of CFs in both of VDCs was found satisfactory in terms of its sustainability though most of the population in the study rely on forest resources. However, there was a huge gap between demand and supply of fuel wood in both the VDCs; comparatively greater in Khandeswori because huge amount of fuelwood is used for space heating during cold winters.

In contrast to Khandeswori VDC, the condition of all five livelihood assests/capitals have been enhanced a lot in Latinath VDC. Livelihood of Khandeswori VDC was found more vulnerable due to high dependence on Yarshagumba. The governance of the CFs was found satisfactory in terms of participation, transparency, equity of poor, DAGs and women. It is concluded from the study that the area has contributed a lot in livelihood upliftment of the people. Resource allocation pattern is equitable and the local people played a crucial role for the conservation as they are found aware of the return they get with the proper management. The recommendations of the present study are as follows:

- Disadvantaged and the marginalized groups of people should be encouraged to participate in forest management activities.

- Income generation and capacity building program should be effectively run at local level.

- Diversification of livelihood option in Khandeswori VDC is highly recommended.

- Further in-depth study is recommended on the linkage of conservation and livelihood aspects from the area.

\section{ACKNOWLEDGEMENTS}

We are thankful to the staffs of VDC office, District Forest Office, Department of National Parks and Wildlife Reserve and UGC Nepal for their financial support during the course of this research work. We are also thankful to Dr. Man Dev Bhatt for reviewing the paper and moral support.

\section{REFERENCES}

Buck, L. E., S. Shames, and S. Scherr (2007). Reframing the protected areas-livelihood debate: conserving biodiversity in populated agricultural landscapes. Wildlife Conservation Society/Working Paper, 32, 130-144.

Cincotta, R.P., and R. Engelman, (2000). Nature's place: human population and the future community forestry? Journal of Forestry and Livelihood 3(1), 78-90.

DNPWC. (2013). Api-Nampa Conservation Area Retrived 2013/1028, 2013 from Gautam, K.H. (2006). Forestry, politicians and power perspectives from Nepal's forest

Naughton-Treves, L., M. B. Holland and K. Brandon (2005). The role of protected areas of biological diversity: Population Action international.

Ojha, H., L. Persha, and A. Chhatre, (2009). Community forestry in Nepal - A policy innovation for local livelihoods. International food and policy research institute discussion paper 00913.

Pokharel, B.K. and M. Nurse (2004). Forest and people's livelihood: benefiting the poor from community forestry. Journal of Forest and Livelihood 4(1), 19-29.

Redford, K. H. and Fearn, E. (2007). Department of Sociology/Anthropology, Tribhuvan University, Kirtipur, Nepal. Protected areas and human LIVELIHOODS: WCS Institute, Wildlife Conservation Society.

Scherr, S.J., and McNeely, J. A. (2008). Biodiversity conservation and agricultural sustainability: towards a new paradigm of 'eco-agriculture' landscapes. Philosophical Transactions of the Royal Society B: Biological Sciences, 363(1491), 477-494. series (17).

(Received 11 May 2017, revised accepted 04 July 2017) 